\title{
Effective Management of Private Schools in Nigeria: Necessity for Governments' Intervention
}

DOI: https://doi.org/10.47175/rielsj.v1i2.87

\section{| John Oluyemi Egbebi ${ }^{1}$ | Olayinka Tijani Wakili ${ }^{2}$}

\author{
1,2 Department of Educational \\ Foundations and Curriculum, \\ Educational Administration \\ and Planning Section, Faculty \\ of Education, Ahmadu Bello \\ University, Zaria, Nigeria
}

2yinkawakeel@yahoo.com/ yemiegbebi@yahoo.com

\begin{abstract}
Private schools and owners invest a lot of worthwhile input in the provision of functional educational service delivery thus paving way for further access, equity and fair play to every intending learner as complement to the effort of government, the public school providers in Nigeria. This development actually met the world declaration of the expectation from all nations of the world to provide mass, quality and free education to all citizens. By and large, education service delivery as a social service requires huge sum of money in its operations across all levels of educational institutions - basic, post basic and tertiary. The paper examined effective management of private schools in Nigeria and the necessity for governments' intervention. In a nutshell, the paper espoused: the world demand on provision of quality education; available sources of funding for private school ownership; challenges of private school ownership and management; justification for the establishment of private schools to support government established institutions; comparism of funding and management pattern of private schools in Nigeria and diaspora; and core constraints of private schools. The paper concludes and recommends that, respective governments, their agencies and parastatals should participate actively in rendering adequate support regarding award of grant-in-aid to owners of private schools; and that cost of registration and set up cost on infrastructural facilities for private schools - low, medium and high scales should be cut down by FME or SMoEs, ZIE, LIE, UBEC, $T R C N$, and similar institutions thus, affordable to create more access to learners with standards.

KEYWORD

Effective Management, Private Schools; Government Public Schools; Funding; and Government' Intervention
\end{abstract}

\section{INTRODUCTION}

The management and operations of private schools in Nigeria have gone a long way to assist nations globally on the problem associated with complexities of learners' continuous population explosion; and simultaneously with access to school enrollment, attendance and retention by all school going-age children, which resulted to low academic achievement, dropout rate and or out of school children. Of great importance is the urge to provide functional education to all in line with world declaration. Education is an instrument for conserving, transmitting and renewing culture, the sum, total of person's experience from one generation to another and hence one can say it is compulsory, (Mallinson, 1980; Moore, 1982). 
The cost of education is quite enormous which requires alternative mode of funding as government finds it difficult to bear alone hence require the attention and participation of other interested group of persons, organizations and individual to render an helping hands in the provision of functional education to all citizens (Organization for Economic CoOperation and Development, OCED, 2012). This development may be justifying one of the reasons for the establishment of private schools in the promotion and provision of effective education service delivery. Of great importance is the idea of public-private partnership for the provision of essential services like education. Public-private partnerships (PPPs) in education have gained attention and influence over the past few decades, as witnessed by the growing number of collaborations between the private sector and the state to help governments around the globe meet their educational needs. They are increasingly viewed as providing a way of meeting the Education for All goals Patrinos Barrera-Osorio, \& Guáqueta (2009), and, more recently, the Sustainable Development Goals. Furthermore, Termes, Bonal., Zancajo, \& Verger (2015), defined PPP contracts as some sort of durability between public and private actors, in which they jointly develop products and services and share risks, costs and resources that are connected with these products. Government has traditionally provided for the infrastructure and other needs of learners across educational institutions requirements of the country from budgetary appropriations in similar private organization apart from education sector. At the best of times, annual budgetary appropriations hardly meet expenditure requirement in a timely and sustainable manner (Chinyere, 2011). At this juncture, the gestation and cost of setting up private school effectively and efficiently faced with a lot of challenges. Take for instance, Ministry of Education, Kaduna State press release tagged, 'all schools remain closed' was signed by Sheu Usman Muhammad, P.hD. who is the Commissioner for Education wrote in paragraph four that, "while the government is encouraging schools to continue their lesson through e-learning to keep children busy and avoid them being idle, no school fees should be collected for that purpose' (Ministry of Education Press Release, 2020). The inference from here is that, where does the Commissioner for Education expected private schools to get returns on their investment for e-learning education service delivery? More so, what about payment of teachers' salaries during COVID 19 pandemic period? Expenses on school plant and facilities provisions and other overhead are always on the high side accounted for the reason why some of the learners in such schools learnt in an non-conducive environment.

Not to mince word, the central focus of Universal Basic Education was to guarantee equal access by all children of school age to educational advantage at the foundational level of basic education being the starting point. Driving forces behind universal high quality education are the six Education For All (EFA) goals and the Millennium Development Goals. The Education for All Track Initiative is a global initiative to support basic education, launched in 2002 by donor governments under the organizational leadership of the World Bank (Okugbe, 2009).

The great public benefits of education have historically prompted governments to assume the primary role in managing and funding schools. Recently, a growing interest in improving school quality and student outcomes, and a quest for greater school choice for parents and students, and for more creativity and innovation in the schools, themselves, have challenged the notion of government's primacy in education (OECD, 2006; Brewer and Hentschke, 2009; PISA 2009 Database (OECD, 2010) and Education at a Glance 2011: OECD Indicators (OECD, 2011). The reflection at this juncture pinpointed that government cannot claim total responsibility to provide quality education for all learners due to huge cost of education as necessity and very compulsory for all citizenry. This 
trend, emerging in a number of countries, is based on the belief that the public interest in education can be better served by also involving private entities, including parents, nongovernmental organizations and enterprises, in addition to government agencies, in managing and funding schools (OECD Indicators OECD, 2011)..

School establishment requires huge sum of money for successful implementation of government policy contained in the National Policy on Education since education as a social service requires huge cost in operations (Olaolu, 2018). As higher as the cost of establishment may be, it is expected to be provided for all citizens regardless of tribes, races, ethnicities and culture generally. The training of children and adolescents in the norms and aspirations of the nation, states and local people is a very veritable instrument for national integration and development (Egbebi, 2019). Most of the value of traditional education of self-reliance on a particular vocation has been eroded. It was expected that educational reforms or re-organisation would be carried out to enable Nigeria's education cater for the future professional needs of school attendees (Ayeni, 2000). Private schools managers of education at the federal, state and local governance of schools have been doing this. This paper hence, examined the effective management and funding of private schools in Nigeria and the necessity for government intervention.

\section{DISCUSSION}

\section{The World Demand on Provision of Quality Education}

The stipulation is that nations of the world must provide equal access of education for every child. Up till present, this welcomed demand has not been met by public providers of education service. It was a direct response to the pledges made at Dakar in 2000 and at Monterrey in 2002, which said, among other things, that the international community should provide the necessary resources to countries committed to achieving the EFA and MDG goals, now sustainable development goal. As postulated by Okugbe (2009), the Millennium Development Goals (MDGs) item two adopted by world nations in 2000 proposed that, by 2015, children of educable age should have free, affordable and accessible education. As at the end of 2015, the aim was not attained and so creates another room for Sustainable Development Goal, SDGs. All the same, the item is a response to the world conference of "Education For ALL (EFA)" held in Jomitten, Thailand from 5th to 9th March 1990, the major trigger for the birth of basic education gives freedom to all children, enjoys qualitative education service delivery at no cost (Okugbe, 2009).

Early childhood/primary level of education system is the root for post basic and tertiary educational levels anyway. Nevertheless, population statistics of Nigerians stands at almost 200 million people (National Population Commission, 2006 and Population Reference Bureau, 2008). Still on population rate confirmation, records of Nigerian Demography by World Bank, CIA World Facebook, Wikipedia, and National Population Commission showed that Nigeria population in 2018 stands between 170 million and 200 million. This postulation connotes that schools established by government cannot give access and equity to all learners due to known factors of paucity of fund and unknown factors that are usually faced by the interested private school settlers respectively. As if this is not enough, learners' academic achievement in most of the private schools is found to be above that of government owned schools sometime (Yusuf and Adigun, 2010). The parental socioeconomic factors dictate the kind of school type that every learner would have access to attend. There were low cost and high fee paying registered and unregistered private schools around. 


\section{Available Sources of Funding of Private School Ownership}

According to Beula Land Academy, Oyo State, proprietor manual for establishment (2020), private schools do source for fund on their own volition to set up schools with all forms of overheads and other costs for financing. He however, claimed that the school at inception received an award from Universal Basic Education Commission Board for a period of time and in the long run, the assistance stopped. The extent of the award was granted to the mentioned school due to influence of owner. Conventionally, available sources of fund to private school owners include: personal savings; loans from banks; cooperatives; local money lenders with outrageous interest; and probably few donations as stipulated in Beula Land Academy (Egolum, 2002., Umoh, 2017., and Egolum, Umoh and Onyejiaka, 2017). For the plans of private school owners of higher taste, the cost of investment on infrastructure: purchase of school site; building of blocks of classrooms and administrative office, construction of school football field, teachers' staff room, way-inout of school premises, among other are usually high.

\section{Challenges of Private School Ownership and Management}

Gestation period for setting up a private school is never an easy task, most especially for small and medium scale business promoters/managers. Obtaining loans from friends and even banking institutions always remains a herculean task due to conditions attached to lending by such institutions and organizations. Research carried out by some scholars has revealed that there is a positive correlation between the physical environment of the school and students' academic performance but majority of private school owners did not have befitting physical environment (Onyeagbako, 2014). Physical environment of some private schools are nothing to write home about. The costs of siting of school location, building classes, staff recruitment and a host of other expenditures are great bearing on the present economic crisis across nations of the world faces and in Nigeria too.

Some of the existing private schools still bedeviled with challenges of inadequate infrastructural facilities most especially the low cost private schools due to inadequate funding logistics. Studies by various scholars Asodike (2005) and Asiabaka (2008) have shown that where physical resources are not adequately available, the following could be observed:

- Poor academic performance by students;

- Poor attitude and disciplinary problems among staff and students;

- Poor concentration resulting from poor quality of air;

- High rate of absenteeism among staff/students;

- Low morale of teachers/students;

- Poor job satisfaction;

- Poor concentration and pupils' participation in the classroom; and

- Over-crowding.

\section{Justification for the Establishment of Private Schools to Support Government established Institutions}

The significance of private education in the establishment of schools cannot be over emphasized. The Federal Republic of Nigeria, FRN (2014) confirmed the fact that the policy gives a chance to the establishment of private schools to support the existing public schools. However, it fails to specify the level of support to be accorded for the smooth running of such. A survey conducted by United Nations Children Education Fund, UNICEF, (2018) indicated that the population of out of school children in Nigeria has risen 
from 10.5 million to 13.2 million, the highest in the world so far. Most of these children are in Nigeria's northern States of Borno, Yobe and Adamawa where book haram insecurities have disrupted academic activities.

The name 'Universal Basic Education' ordinarily would have suggested that every Nigerian child, without exception would have access to basic education without hindrance. But, unfortunately, it has never been possible for UBEC to fulfill the EFA goal for giving equal access to all children; so, one could conclude that private school owners have been assisting the government in the provision of quality education in this regard. The importance of education reflects huge expenditures made by government at various levels on provision and services and the persistent cry by the public for Government to implement 26\% UNESCO recommendation (Agi, 2013). This effort from history is meant for public school owners and not private school managers. As noted by Gbadamosi (2005) the argument in favor of provision of education by the private sector include, among others, the right of individual or groups to have a choice in education, efficiency consideration and relieving the government of the heavy burden of funding education.

All reports showed that $42.8 \%$ or $72,812,961$ are aged $0-14$ are in public schools while that of private schools could not be ascertained due to the influx of registered and unregistered private schools. In view of the enormous population size of the aged $0-14$, the provision of education requires massive expansion. In recognition of this, government at every level not only desire private sector connections in funding but also in active participation in provision of functional education service delivery (FRN, 2014).

\section{Comparism of Funding and Management Pattern of Private Schools in Nigeria and Diaspora}

Deepen categorized privately owned schools in Nigeria under two categories namely lowcost fee paying schools and high-cost fee paying schools. According to PISA (2012) report In Sweden, Finland, the Netherlands, the Slovak Republic and the partner economy Hong Kong-China, principals in privately managed schools reported that over $90 \%$ of school funding comes from the government, while in Slovenia, Germany, Belgium, Hungary, Luxembourg and Ireland, between $80 \%$ and $90 \%$ of funding for privately managed school does. In contrast, in the United Kingdom, Greece, the United States, Mexico, and the partner countries government contribute at a low standard. In economies of Albania, Kyrgyzstan, Tunisia, Uruguay, Dubai (UAE), Qatar and Jordan, 1\% or less of funding for privately managed schools comes from the government; in New Zealand and the partner countries and economies of Panama, Brazil, Chinese Taipei, Kazakhstan, Peru and Shanghai-China, between $1 \%$ and $10 \%$ comes from owners of schools.

PISA (2012) established whether low or high fee paying schools that promotion, establishment in terms of general management and funding of private schools is enormous. Other available data indicates that there are households below the poverty line and from the poorest families in private schools. Using the expansive definition of poverty noted earlier, Tooley (2013) estimated that $35 \%$ of households below the poverty line were in public schools, $27 \%$ in low cost private schools, and $34 \%$ in medium or high cost private schools and this development is bound to affect private schools owners in a negative way.

Wealth index data collected in 2016 on students from a sample of public and low and medium cost private schools found students from the poorest docile in private schools, but also that poorer students were more likely to be in public schools. Taken together, this suggests that changes in private schools (at most fee levels) are likely to reach students from poor households, and that changes in low cost private schools have the highest likelihood to reach the poorest students. These data do not, however, allow us to be 
confident about how many students from poor households in private schools that these interventions are reaching.

The federal Republic of Nigeria allows private participation to offer their contribution and thus found schools but no specific statement on what kind of financial support they will give in support of operations (FRN, 2014). It was even reported that government fund disbursement on public schools across all levels of educational institutions is not enough. Sources and systems of fund from Nigerian universities have proven inadequate and innovative or alternative funding mechanism has become very important more than ever before. The federal government of Nigeria has been investing less than two per cent of Gross Domestic Product (GDP) on public education in the last 10 years (Faboyede, Faboyede and Fakile, 2014). The expected groups that ought to support and provide for the need of private school funding are either to not giving the right attention to the need of private schools as against public school financing.

According to Okojie (2007), the National Steering Group (NSG) was set-up comprising the relevant stakeholders, namely:

i) Federal Ministry of Education (FME);

ii) Federal Ministry of Employment, Labour and Productivity (FMEL\&P);

iii) National Commission for Colleges of Education (NCCE);

iv) Universal Basic Education Commission (UBEC);

v) Teachers' Registration Council of Nigeria (TRCN);

vi) Nigeria Union of Teachers (NUT);

vii) International Labour Organization (ILO); and

viii) National Teachers' Institute (NTI).

\section{Core Constraints of Private Schools}

In 2015, the DEEPEN baseline study discovered that more than $70 \%$ of the low and medium cost school teachers surveyed did not deliver competent lessons that encourage pupils to employ critical thinking skills and that many head teachers were not providing adequate mentoring and support for teachers. Developing Effective Private Education in Nigeria (DEEPEN), (2018) adopt the UK Department for International Development (DFID) decided to adopt a market systems approach to address the core constraints in the private school market system, identified in 2011 as:

- soft competition among schools due to a growing population that allows poor schools to survive;

- missing support functions, including access to finance and professional services, such as teacher training;

- a heavy-handed and non-supportive regulatory regime that forces the majority of schools to operate 'beneath the radar' of the government; and

- $\quad$ poor and uneven information for parents about school quality, and in general about the scale and needs of the private school sector.

DEEPEN however, aims to improve learning outcomes and conditions for children in private schools, particularly for children from poor households.

\section{CONCLUSION}

The paper concludes that in the light of the fact that the number of school going age children kept on increasing beyond what the government financed public schools could provide functional education for, there is the need for the intervention of private school developers and managers to establish schools on low, medium or large scale basis. More 
so, education as a social service requires huge sum of money for the establishment which any government of the day cannot provide for adequately. Since the inception of the Universal Basic Education Commission to give basic and functional education to all children, about 13.5 million children are still out of school in Nigeria most especially in the Northern part of the country. Other stake holders for school governance such as the National Steering Committee namely: Federal Ministry of Education (FME); Federal Ministry of Employment, Labour and Productivity (FMEL\&P); National Commission for Colleges of Education (NCCE); Universal Basic Education Commission (UBEC); Teachers' Registration Council of Nigeria (TRCN); Nigeria Union of Teachers (NUT); International Labour Organization (ILO); and National Teachers' Institute (NTI) only cater for public schools and less for private school organizations. DEEPEN had performed to best of his capacity in the finance of private schools most especially in Lagos including the Federal capital territory out of 36 states of Nigeria. In a nutshell, the idea is to call on the government and his parastatals and agencies to intervene in the funding of private education since the population kept on increasing that has led to increase in school attendance, reduction in the out of school children and probably enhanced learners' academic performance in both public and private school respectively and more so that the universal declaration stipulated that all children are to be in school for national development and growth.

Respective government, their agencies and parastatals should participate actively in rendering adequate support regarding award of grant-in-aid to owners of privates schools..

Cost of registration and set up cost on infrastructural facilities for private schools - low, medium and high scales should be cut down by FME or SMoEs, ZIE, LIE, UBEC, TRCN, and similar institutions thus, affordable to create more access to learners with standards.

Other international donor agencies and development partners like UNICEF, WHO, UNDP among others should emulate DEEPEN in providing for staff development and offering of financial assistance in private schools. World-class educational resources, starting with educational videos and other Information Technology materials and equipment should be supplied to students and teachers.

Private school owners should save for the raining days through savings of excess profit sometime through the purchase of bond from government as a secured investment that could never fail.

National association of the union of private school owners should set standards to monitor and evaluate the services of private school owners to be really a functional one that did not derail from government policy.

\section{REFERENCES}

Agabi, C. O (2014). Teaching and resource management in education. Port Harcourt: Rodi Agi, U. K., and Eremie, I. (2018).Effective implementation of universal basic education in Rivers State: Role and utilization of physical. International Journal of Scientific Research in Education, 11(1), 127-136.

Amaeze, F. E., and Odunlade, P. K (2013). Assessment of the status of educational facilities for quality education delivery in UBE schools in Imo State, Nigeria. African Journal of Educational Research and Development, 6(1), 9-21.

Ammermuller, A. (2005). Educational Opportunities and the Role of Institutions, ZEW Discussion Paper, No. 44, Centre for European Economic Research, Mannheim.

Asiabaka, P. I. (2008). The need for effective facility management in schools in Nigeria. New York Science Journal. Retrieved from www.sciencepub.org/newyork/0102/02/020366- Asiabaka facilities. 
Asodike, J. D (2005). A diagnosis of the use of building equipment and facilities of government craft development centre, Port Harcourt. University of Port Harcourt, Nigeria. Unpublished manuscript.

Ayeni, M.A. (2000). Secondary Education: A New Look at Nigerian Adolescents and Young Adults. A paper presented at the 18th Annual Conference of Philosophy of Education Association of Nigeria, 16th October - 19th October.

Bifulco, R., Ladd, H. F. and Ross, S. L. (2009). The effects of public school choice on those left behind: Evidence from Durham, North Carolina. Peabody Journal of Education, 84, 2, 130-149.

Böhlmark, A. and Lindahl, M. (2007). The impact of school choice on pupil achievement, segregation and costs: Swedish evidence in A. Böhlmark (ed.), School Reform, Educational Achievement and Lifetime Income, Department of Economics, Stockholm University, Stockholm, 1-63.

Brewer, D. and Hentschke, G. (2009), An international perspective on publicly-financed, privately-operated schools in M. Berends (ed.) Handbook of Research on School Choice, Routledge, New York, 227-246.

Chinyere L.(2011). Understanding the risks of public private partnerships in construction and infrastructure development before the 2008 global financial crisis. Proceedings of AABRI Conference, Las Vegas, October 6-8, 2011.

Couch, J., Shugart, W. and Williams, A. (1993). Private school enrollment and public school performance. Public Choice, 76, 301-312.

Egbebi, J. O. (2019). The new history of education in Nigeria. Zaria. Ahmadu Bello University Press.

Egolum, C. C. (2002). Real property investment and management. Enugu, Nigeria. SNAAP Press Limited.

Egolum, C. C., Umoh, F. I., and Onyejiaka (2017). Sources of available to private investors for housing development in Nigeria. British Journal of Environmental Science, 5 (3), 16-29.

Epple, D., Figlio, D.N. and Romano, R.E. (2004). Competition between private and public schools: testing stratification and pricing predictions. Journal of Public Economics, 88, 7, 1215-1245.

Fafunwa, B.A. (1974). History of Education in Nigeria. George Allen and Unwin Ltd., London.

Filer, R. K. and Munich, D. (2003). Public Support for Private Schools in Post-Communist Europe: Czech and Hungarian Experiences in D.N. Plank and G. Sykes (eds.), Choosing Choice: School Choice in International Perspective, Teachers College Press, New York, 196-222.

Fiske, E.B. and Ladd, H.F. (2000). When Schools Compete: A Cautionary.

Geller, C.R., Sjoquist, D.L. and Walker, M.B. (2006). The effect of private school competition on public school performance in Georgia. Public Finance Review, 34 (1), 4-32.

Green, F. (2011).The changing economic advantage from private schools. Economica, Digital Object Identifier: 10.1111/j.1468-0335.2011.00908.x.

Greene, K.V. and Kang, B.G. (2004). The effect of public and private competition on high school outputs in New York state", Economics of Education Review, 23, 497-506. http://dx.doi.org/10.1787/9789264175006-en, ISBN 978-92-64-17491-7.

Mallinson, V. (1980). An Introduction to the study of comparative education. Heinemann Educational Books, London. 
Ministry Of Education, Kaduna State. (2020). Press release: All school should remain closed. Signed by the Commissioner for Education on $2^{\text {nd }}$ May, 2020.

Moore, T.W. (1982). Philosophy of education: An introduction. Routledge and Kegan Paul, London.

OECD (2010a), Education at a Glance 2010: OECD Indicators, OECD Publishing.

OECD (2010b), PISA 2009 Results, What Makes a School Successful? Policies, Practices and Resources (Volume IV), OECD Publishing.

OECD (2012). Public and private school management: How funding and management and funding relates to the socio-economic profile. OECD Publishing, http//dx.doi.org/10.1787197892264175006-en, ISBN 978-92-64-17497-7.

Okugbe, G. E.(2009). The challenges affecting the implementation of the universal basic education (UBE) in Delta State, Nigeria. Kamla Raj Journal of Socio-Science, 20(3): 183-187 (2009).

Onyeagbako, S. O. (2014). Facilities maintenance and renewal. In F. N. Obasi \& J. D. Asodike (eds.), Educational resource management. Port Harcourt: Pearl Publishers. 136.

Organization for Economic Cooperation and Development, OECD, Programme for International Student Assessment, PISA, (2012). Public and Private Schools: How Management and Funding Relate to their Socio-economic Profile, OECD Publishing, http://dx.doi.org/10.1787/9789264175006-en, ISBN 978-92-64-17491-7.

Patrinos, H.A., Barrera-Osorio, F. \& Guáqueta, J. (2009) The Role and Impact of PublicPrivate Partnerships in Education, Washington, DC.

Population Reference Bureau (2008). Data by geography: Nigeria. Population reference Bureau.

Termes, A., Bonal, X., Zancajo, A. \& Verger A. (2015). Public-Private partnerships in Colombian Education: The Equity and Quality Implications of Colegios en concession. Privatisation in Education Research Initiative (PERI) Paper No 66.

Tooley J. (2018). Training the trainers, creating a market for school improvement services in Lagos. Developing Effective Private Education Nigeria (Deepen): Cambridge Education publication.

Umoh, F. I. (2017). Real property investment and management, $2^{\text {nd }}$ edition, Awka, Nigeria. Christon Int. Limited.

United Nations Children Education Fund, UNICEF (2018). In Nigeria, more than 13.2 million school-age children are out-of-school. VOA news.com/Africa/dec 11, 2018/03.40am.

Woessmann, L. (2006). Public-private partnerships and schooling outcomes across countries. Cesifo Working Paper, No. 1662, Center for Economic Studies, Institute for Economic Research, Munich.

Woessmann, L., (2009), School Accountability, Autonomy, and Choice around the World, Edward Elgar, Cheltenham.

Yusuf, M. A., and Adigun, J. T. (2010). The influence of school sex, location and type on students' academic performance. International Journal of Education Science, 2(2) 81.101 . 